\title{
An exploratory study of financial well-being among Malaysian households
}

Financial wellbeing among Malaysian households

\author{
Nurul Shahnaz Mahdzan, Rozaimah Zainudin, Mohd Edil Abd Sukor, \\ Fauzi Zainir and Wan Marhaini Wan Ahmad \\ Department of Finance and Banking, University of Malaya, Kuala Lumpur, Malaysia
}

\begin{abstract}
Purpose - The purpose of this paper is to empirically explore the financial well-being (FWB) of Malaysian households and to construct a subjective FWB index with present and future time perspectives.

Design/methodology/approach - Data were collected from 1,867 respondents across five major regions in Malaysia. Adapting the InCharge Financial Distress/Financial Well-being (IFDFW) Scale by Prawitz et al. (2006) and the method of computing an index by Devlin (2009), this study develops an FWB index using subjective measures that include future time perspectives (retirement). The index was employed to measure the FWB across low-, middle- and high-income groups and socio-demographic characteristics.

Findings - This study finds evidence that Malaysians' FWB is at an average level (46.8). Middle-income households' FWB (46.1) flanks between the financial well-being index (FWBI) levels of the low-income (37.4) and high-income households (58.7). Across age groups, education levels and employment sectors, the FWB of Malaysians significantly varies, although not across different ethnics, religions, zones and residential areas. Overall, the results suggest that the detrimental effects of FWB are perceived by all Malaysian households nationwide regardless of their religion, ethnicity and residential areas.

Practical implications - The results of this study complement the other well-being indices used by policymakers and may serve as a useful input for government and policymakers for them to formulate appropriate strategies to promote higher FWB of Malaysian households based on their socio-demographic characteristics.

Originality/value - This study used primary data and developed a subjective FWB index that leverages on people's perceptions of their own financial well-being while including present and future time perspectives. The main contribution of this paper is to construct an index that is easily interpretable and that complements the existing FWB indices, and to identify the segments of society that have low vis-à-vis high FWB.
\end{abstract}

Keywords Malaysia, Household income, Index, Households, Financial well-being, Subjective measurement Paper type Research paper

\section{Introduction}

Global economic uncertainties since the past decade and in recent years have had an adverse impact on many households across nations, including Malaysian households. The Malaysian economic landscape has observed increasingly competitive business environments, tough labour market conditions and high costs of living, which have affected households and consumers at large. Firms across various sectors have had to downsize their workforce (The Star Online, 2015; Balakrishnan, 2016), and such actions have detrimental effects on the well-

(C) Nurul Shahnaz Mahdzan, Rozaimah Zainudin, Mohd Edil Abd Sukor, Fauzi Zainir and Wan Marhaini Wan Ahmad. Published in Journal of Asian Business and Economic Studies. Published by Emerald Publishing Limited. This article is published under the Creative Commons Attribution (CC BY 4.0) licence. Anyone may reproduce, distribute, translate and create derivative works of this article (for both commercial and non-commercial purposes), subject to full attribution to the original publication and authors. The full terms of this licence may be seen at http://creativecommons.org/licences/by/4.0/ legalcode

The authors would like to thank the Malaysian Ministry of Education under the Fundamental Research Grant Scheme for providing the financial resources that assisted in the conduct of this study (Research Grant No. FP025-2016).

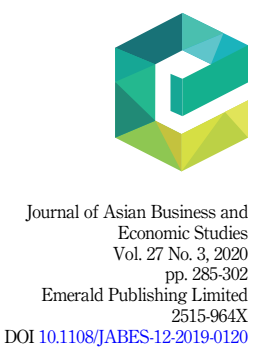

Received 4 December 2019 Revised 8 March 2020 26 June 2020 
JABES 27,3

286

being of workers due to loss of jobs and their source of income (Helliwell et al., 2014). Meanwhile, the implications of increasing costs of living are a strain on households' purchasing power and an upsurge in the use of credit and debts (Zainol et al., 2016; Azman et al., 2017). Ultimately, these economic challenges imply that there may be an undesirable effect on the financial well-being (FWB) of Malaysians (Subramanian et al., 2014), plausibly developing into other socio-economic adversities such as increased unemployment, poverty and crime.

Recognising these financial hardships, over the years, the Malaysian government has continuously put in concerted efforts to uplift the state of well-being among its society. One of the National Key Results Areas (NKRAs) in the Government Transformation Programme (GTP) launched in 2011 specifically addressed the issue of rising cost of living in Malaysia. These issues have been given due attention by policymakers especially for the low-income household (denoted as the bottom $40 \%$ or B40 group) and middle-income households (denoted as the middle $40 \%$ or M40 group), as these two income groups constitute a significant $80 \%$ of total households in Malaysia. Therefore, ensuring that these segments of society attain their desired level of FWB continues to be a major concern to the Malaysian government. The main thrusts of the recent federal budgets are clear indications of the government's attempts to elevate societal welfare, particularly for the B40 and M40 households. In the national federal budgets, various tax incentives have been enforced to help increase the disposable income among both income groups' households. In addition, numerous initiatives to increase knowledge, skills and educational attainment have also been implemented in efforts to improve the livelihood of these segments of society.

To gauge the level of Malaysians' overall well-being, the main social indicator used by the policymakers is the Malaysian Well-being Index (MWI). Defined as "the physical, social and economic benefits that contribute to the enhancement in the quality of life and satisfaction of an individual, family and the economy" (EPU, 2013), the MWI measures the well-being of society from economic and social perspectives. However, although indexes such as the MWI are useful indicators of a society's well-being, such objective measures have their limitations. Computations of MWI that is based on monetised components of economic activity such as income and expenditure data (Pudney, 2011) ignore the psychological perceptions and emotional aspects of individuals on their own state of well-being. Despite having the same level of wealth or income, one's happiness and satisfaction may vary from another individual due to differences in feelings, beliefs, values, habits and preferences (Prawitz et al., 2006). Furthermore, the accuracy of monetary measures is highly susceptible to measurement error due to missing values or inaccuracy of reporting (Hurd et al., 2003).

In view of the aforesaid limitations of objective measures, subjective well-being measures have gained popularity and are accepted as reliable scientific appraisals of life satisfaction across many disciplines (e.g. Diener et al., 2002; Prawitz et al., 2006). In the context of Malaysia, the Malaysian Family Well-being Index (MFWBI) has been used as a subjective measure of family well-being. However, as will later be discussed in Section 2.2, the MFWBI has its limitations due to its limited scope on families with children aged between 3 and 24 years. Thus, its generalisability to Malaysian households can be viewed as insufficient. Furthermore, the literature still shows inconsistencies and the lack of a unanimously agreedupon definition and measurement of subjective financial well-being (Brüggen et al., 2017). Therefore, it is believed that continuous works in measuring financial well-being is still relevant in today's highly challenging financial landscape.

In Brüggen et al.'s (2017) comprehensive conceptual paper on FWB, they propose a research agenda for FWB studies from which this paper is partly motivated. In particular, they suggest that researchers should explore the "mismatch between objective and subjective indicators of well-being" and "develop reliable and valid measures for FWB on individual, household, and group levels" (Brüggen et al., 2017, p. 234). Therefore, this study will construct 
an FWB index (FWBI) that is modified and adapted from two studies - Prawitz et al. (2006) and Devlin (2009) - to encapsulate the psychological perceptions and emotions to better reflect Malaysian households' financial satisfaction. The adapted FWBI addresses the mismatch in the present MWI (objective measure) and MFWBI (subjective measure) to provide a clearer picture of the FWB of Malaysian households.

Motivated by Brüggen $e$ t al.'s (2017) research agenda, this paper has two main objectives. The first objective of the paper is to compare the level of FWB among Malaysian households of different income groups, namely, the low-, middle- and high-income groups (i.e. the B40, M40 and T20, groups, respectively). Finally, the second objective of this paper is to analyse the differences in FWB across socio-demographic characteristics. The second objective addresses another suggestion made by Brüggen et al. (2017), that is, to conduct studies that will assist policymakers develop and implement interventions to improve FWB. Policymakers may use the FWBI along with the objective index to close the gap between the possible inconsistencies of the objective and the subjective well-being index. Based on the findings, the policymakers will be able to identify the vulnerable groups in the population that have low $\mathrm{FWB}$, according to their socio-demographic profile, and can therefore introduce policies that can effectively improve the FWB of the financially vulnerable households.

This study has two contributions. First, the constructed subjective FWBI that is modified and adapted from two studies, Prawitz et al. (2006) and Devlin (2009), encompasses two time dimensions: present and future financial satisfaction. Our measurement of FWB covering two time dimensions is motivated from the suggestion of Brüggen et al. (2017). Second, this paper provides a detailed description of the differences in FWB across household income and sociodemographic characteristics in the Malaysian context. The FWBI of this study can be used to complement the existing two well-being indexes where we offer a subjective measure of financial satisfaction that is tested across different households' socio-demographic characteristics. The derived index will give policymakers a clear and holistic indication of the general state of financial well-being of Malaysian households. The results of this study will support evidence-based policymaking to enhance the financial satisfaction and overall quality of life of vulnerable groups.

In the next section, we review the literature on FWB. In Section 3, the methodology of the study is explained, and in Section 4, we analyse the data and discuss the results. In Section 5, we conclude the paper by offering policy implications for policymakers and recommendations for future research.

\section{Literature review}

\subsection{Financial well-being}

FWB is one of the subcomponents of personal well-being, and its definition has varied among researchers. Originally, FWB was described as a state of happiness or general satisfaction with one's financial situation, encompassing a person's satisfaction with income and savings, a sense of material security, perceptions of opportunities available and a sense of fairness of the reward distribution system (Strumpel, 1977). Other researchers define FWB as "a state of being financially healthy, happy, and free from worry" which is typically based on a subjective appraisal of one's financial situation (Joo et al., 2008; Sabri and Falahati, 2012). The definition of FWB has developed from simple happiness or general satisfaction about one's material or financial condition, to a complex perception that includes the combined perception of both material and non-material aspects of an individual's financial situation (Delafrooz and Paim, 2011). Brüggen et al. (2017) conclude that the conceptualisation of FWB in the literature is fluid and unclear, leading to many inconsistencies in its definition, and hence its measurement.

The literature shows that FWB has been measured using objective and/or subjective measures. Brüggen et al. (2017) articulate that there are three clusters of measurements of
Financial wellbeing among Malaysian households 
JABES 27,3

288

FWB - those that use objective, those that use subjective measures or those that combine both objective and subjective measures. In regard to studies that use objective measures, Greninger et al. (1996) develop a comprehensive measurement of FWB consisting of household savings, expenses, asset allocation, insolvency/credit, liquidity position, tax expenses and inflation protection. Other researchers use creditworthiness, amount of available emergency funds, allocation of monthly credit card payments, monthly loan payments, monthly allocation of money for savings and preparation for retirement in the future, as measures of objective FWB (Delafrooz et al., 2010).

Meanwhile, in the second cluster of FWB measurement, Kim et al. (2003) measure subjective FWB as the perceptions regarding debt status, ability to meet monthly expenses and financial satisfaction. Using the measurements of Porter (1990) and Joo (1998), Kim et al. (2003) develop FWB using four items: "satisfaction with personal financial situation", "perceived financial wellness", "feelings about current financial situation" and "level of stress about personal finance". Prawitz et al. (2006) develop an instrument to measure the level of stress and well-being based on an individual's financial condition. Constructed based on a Delphi method, the FWB construct was measured as a continuum ranging from negative to positive emotions towards certain financial conditions. The scale is termed as the InCharge Financial Distress/Financial Well-being (IFDFW) Scale. Numerous studies based on the IFDFW have been conducted in numerous other parts of the worlds, such as in Australia (Gerrans et al., 2014), Nigeria (Kemisola-Christianah et al., 2019), India (Sivaramakrishnan and Srivastava, 2019), Italy (Dickason-Koekemoer and Ferreira, 2019) and Malaysia (Mokhtar et al., 2015).

The third cluster of measurement uses a combination of both objective and subjective measures of FWB. For example, Shim et al. (2009) combine the level of debt (objective measure) with perceived satisfaction of financial status (subjective measure). Porter and Garman (1992) use income level and perceived satisfaction of standard of living, which essentially combine both objective and subjective measures of FWB. Similarly, Lanz et al. (2019) use both subjective and objective measures of FWB in a study on emerging adults in Italy.

\subsection{FWB in the context of Malaysia}

In the context of Malaysia, Jariah (2007) pioneered the works on FWB, and numerous studies have ensued. However, studies on FWB in the context of Malaysia have echoed the inconsistencies in measurements as of those in international contexts. Variations are noted in the number of measurement items of the subjective FWB construct, ranging from four to twelve items (e.g. Sabri and Zakaria, 2015; Mokhtar et al., 2015; Mokhtar and Husniyah, 2017), while others have used objective measures of FWB such as saving and debt-payment ratios (e.g. Zaimah et al., 2013). In addition, the works appear to be rather limited as most of these studies have been based on a relatively small sample size and focused on specific segments of society such as public-sector employees, elderly individuals or college students (e.g. Zaimah et al., 2013; Mokhtar et al., 2015; Mokhtar and Husniyah, 2017; Falahati and Paim, 2011; Yin-Fah et al., 2010). Hence, it can be viewed that FWB measurements in Malaysia are still very much segmented and inconclusive.

In terms of policymaking well-being measures, there are two macro-level indexes being used by the Malaysian government. The first is the MWI measured by Malaysia's Economic Planning Unit (EPU) which is a social indicator that tracks Malaysians' well-being over time. The MWI employs 68 indicators, 14 components and two sub-composites - economic and social well-being. The first composite, economic well-being, consists of five components including income and distribution which are measured based on objective measures such as real per capita income (GNP), disposable income and poverty.

The other well-being indicator used in Malaysia is the MFWBI by the National Population and Family Development Board (NPFDB). Family well-being is defined as " $a$ safe, healthy, 
comfortable harmonious and satisfying family condition" covering aspects such as spiritual satisfaction, psychosocial attributes and financial security (NPFDB, 2011, 2016). The index, which is based on subjective perceptions via survey questionnaires, has thus far been conducted in two cycles - 2011 and 2016. The index covers eight (8) domains ranging from family relationship, family economy, health, safety, family and community involvement, religion and spiritual practices, housing and environment and communication technology. The family economy domain covers financial well-being and financial management indicators. Although the measurement of family well-being in the MFBWI is comprehensive and constructed based on subjective measures, the survey is limited to Malaysian parents with children between 3 and 24 years of age. Hence, the scope of the index is viewed to be inadequate, as it does not represent Malaysian households that are excluded from that criteria.

In view of the above issues in definition and measurement of $\mathrm{FWB}$, we take a similar stance as that of Brüggen et al. (2017) that the subjective approach may be a more appropriate measure since only an individual himself or herself can assess the level of his/her own financial well-being. Therefore, one's level of income will not influence financial well-being since there are so many other heterogeneous factors such as family size, expenses, debt and stressor events that differ from one household to another. In this study, we define FWB as the feeling of self-fulfilment over one's present financial standing, being assured of meeting regular living expenses and emergency costs, possessing financial freedom to conduct activities as one pleases and feeling confident about one's future retirement. This definition differs slightly from that of past studies (e.g. Consumer Financial Protection Bureau, 2015; Prawitz et al., 2006; Drever et al., 2015), as our definition includes two time dimensions, that is, perceived wellbeing in the present moment and in the future (retirement), following the conceptual suggestion of Brüggen et al. (2017).

The present paper attempts to fill the gaps in the literature by providing an all-inclusive subjective definition of FWB that not only covers a more diverse sample encompassing a wider range of households in Malaysia but one that covers the time dimensions of present and future financial situation. The index in this study is converted into a score of 100 , which is easily interpretable. The FWBI used in this study will complement the existing indexes to give a better picture of Malaysians' FWB. We believe that the results of this study will provide evidence that can be useful to policymakers with respect to providing targeted programmes to elevate the state of FWB across Malaysians according to their sociodemographic characteristics.

\section{Methodology}

\subsection{Sample and data}

As of 2019, Malaysia has a population of 32.6 million and 6.35 million households (Department of Statistics Malaysia, 2019). To allow reliable inferences and generalisations to be made of the population, studies should be cautious in obtaining a sample that is sufficiently large and representative of the larger population (Maleske, 1995). Henceforth, given the limited time and resources available, the present study is conducted as a crosssectional study and employs a two-stage sampling approach. In the first stage, a stratified sampling method is conducted to ensure representativeness of households across five major regions in Malaysia (Central, Southern, Northern, East Coast and East Malaysia). In the second stage, respondents were selected based on a convenience sampling approach in which respondents were chosen based on their availability. Primary data were collected by appointment enumerators who approached the respondents from public areas such as neighbourhood areas, shopping malls, bus stations, schools, markets, public hospitals and offices. We acknowledge that convenience sampling method may have its limitations of
Financial wellbeing among Malaysian households

289 
JABES 27,3

290

generalisability; however, this method was deemed acceptable due to its time and cost advantages while still ensuring that a sufficiently large sample was obtained from across Malaysia. Hence, after a two-month period, we managed to obtain a total of 1,867 useable responses for the study. As per Krejcie and Morgan (1970), the sample size is deemed sufficiently large to allow reliable statistical inferences to be made of the population.

Table 1 depicts the segmentations of Malaysia's thirteen states and three federal territories according to five geographical regions. As can be observed, the sampling distribution in the Central and East Coast regions closely resemble the Malaysian population distribution in those respective areas. For the Southern region, the sampling distribution is marginally over by $10 \%$ from the population percentage, while for the Northern and East Malaysia regions, the percentages are less by 5 and $7 \%$, respectively, from the population percentages. In essence, the two-stage sampling approach yielded quite a fair representation of the population according to strata; however, the accessibility of respondents in the second stage of approach using convenience sampling resulted in marginal discrepancies in the distribution. Despite the minor discrepancies, the sample size is viewed reasonable to allow reliable statistical inferences to be made regarding the issues being examined in this study.

\subsection{Financial well-being measurement}

The first and main objective of the paper is to construct a subjective index that is focused on financial well-being for Malaysian household. Following a comprehensive literature review on the subject matter, the measurement for FWB employed in this study is adapted from the well-established IFDFW Scale developed by Prawitz et al. (2006). The IFDFW has been rigorously tested for content and construct validity and is simple and easy to administer (Garman et al., 2007). However, we made minor modifications to suit the definition of FWB, as provided in Section 2, of having two time dimensions (present and future) and also to suit the local Malaysian scenario. In addition, the computation technique for the FWBI was adapted from Devlin (2009) who constructed an index on customer's perceived fairness of financial services. Based on the modified instrument, we conducted a pre-test of the questionnaire with four local and one international scholars in the field, primarily to get their opinions on the suitability of the questions as well as on the translated version of the questionnaire (in the local Malay language). Their comments were taken into consideration, and minor adjustments were made. The questions of the Malay language were proof-edited by a professional editor. In summary, the following modifications that were made are shown in Table 2

The above changes are viewed reflective of our definition of FWB encompassing the present and future time dimension. As a result of the changes, our measurement of FWB comprises of nine (9) items, as opposed to eight (8) items by Prawitz et al. (2006). We retain the

\begin{tabular}{|c|c|c|c|c|c|}
\hline & Region & States & $\begin{array}{c}\text { Malaysian population } \\
(\%)\end{array}$ & $\begin{array}{l}\text { Sample } \\
\text { size }\end{array}$ & $\begin{array}{c}\text { Sample } \\
(\%)\end{array}$ \\
\hline 1 & Central & $\begin{array}{l}\text { Selangor, Kuala Lumpur, Putra } \\
\text { Jaya }\end{array}$ & 25.8 & 526 & 28.2 \\
\hline 2 & Southern & Negeri Sembilan, Malacca, Johor & 17.8 & 515 & 27.6 \\
\hline 3 & Northern & Perlis, Kedah, Penang, Perak & 20.7 & 293 & 15.7 \\
\hline 4 & East Coast & $\begin{array}{l}\text { Kelantan, Terengganu and } \\
\text { Pahang }\end{array}$ & 14.5 & 288 & 15.4 \\
\hline \multirow[t]{2}{*}{5} & East & Sabah, Sarawak, Labuan & 21.0 & 245 & 13.1 \\
\hline & & Total & 100.0 & 1,867 & 100.0 \\
\hline
\end{tabular}

Table 1.

Distribution of sample according to strata 


\begin{tabular}{|c|c|}
\hline Revision & Details \\
\hline Revised item & $\begin{array}{l}\text { The original item "How frequently do you find } \\
\text { yourself just getting by financially and living } \\
\text { paycheck to paycheck?" was changed to "How } \\
\text { frequently do you find yourself eagerly } \\
\text { awaiting for the next pay day?" } \\
\text { The original item "On the stair step below, } \\
\text { mark how satisfied you are with your present } \\
\text { financial situation" was changed to "Are you } \\
\text { satisfied with your personal finances"? }\end{array}$ \\
\hline $\begin{array}{l}\text { Additional } \\
\text { items }\end{array}$ & $\begin{array}{l}\text { How secure do you feel about your retirement } \\
\text { plan? } \\
\text { How confident are you that you'll have a } \\
\text { financially comfortable retirement? }\end{array}$ \\
\hline
\end{tabular}

Justification

The original question was deemed unsuitable in the Malaysian context as the term "paycheck" may not be understood or be relevant to some people

The item was changed to maintain consistency of using a 10-continuum scale as with other items measuring FWB, as suggested by the expert opinion

These two items are added to represent the time dimension of the future
Financial wellbeing among Malaysian households

291

Table 2.

Note(s): The distribution by region is derived from the extrapolated population estimation in 2016 conducted by the Department of Statistic Malaysia (https:/www.dosm.gov.my/v1/index.php? $r=$ column/ctheme\&menu id=L0pheU43NWJwRWVSZklWdzQ4TlhUUT09\&bul_id=OWlxdEVoY1JCS0hUZzJyRUcvZEYxZz09)
Revisions made on the FWB measurement

continuum 10-point Likert scale, indicating low levels to high levels of FWB as per Prawitz et al. (2006). The items for FWB, which have different anchors for its rating scales, are later presented in Section 4.2 (Table 3). Finally, by adopting Devlin's (2009) method, we use the FWB scores to compute the FWBI that is easily interpretable (over a total score of 100).

\subsection{Classification of the B40, M40 and T20 groups}

Our second objective in this study is to provide a detailed description of the differences in FWB across household income groups in Malaysia. To achieve this, we need to categorise the household according to three income levels: the bottom $40 \%$ (B40), middle $40 \%$ (M40) and top $20 \%$ (T20) groups, signifying the percentage of households in the respective income categories as a percentage of the total households in Malaysia. In Malaysia's 11th Malaysian Plan, B40 households are defined as those with household monthly income below RM3,860, middle-income households are those earning between RM3,860 and RM8,320 and T20 households are those earning more than RM8,320 monthly (EPU, 2015) [1].

\section{Data analysis}

\subsection{Descriptive analysis}

The results of the descriptive analyses are presented in Table 3 . The respondents are mainly male $(53.7 \%)$, and about $70 \%$ of the total respondents fell between the age range of 25-44 years of age. In all, $67 \%$ of the respondents were Malay, which is the majority ethnic group in Malaysia. Hence, it is also not surprising that most respondents were also Muslims (73.3\%). The second largest ethnic group is Chinese (12.6\%), followed by Bumiputera Sabah and Sarawak (10.9\%). A total of $41.2 \%$ of respondents were bachelor degree holders, followed by $22.2 \%$ of diploma holders and $14.1 \%$ having passed secondary school. Approximately $70 \%$ of the respondents are married and live in urban areas.

\subsection{Confirmatory Factor Analysis}

A confirmatory factor analysis (CFA) was conducted to test for internal consistency and to establish the underlying latent constructs of the FWB variable. Further to that, a reliability tests were conducted through measurement of Cronbach's alpha. Results of a principal 
JABES 27,3

\begin{tabular}{|c|c|c|c|}
\hline Variables & & Frequency $(n=1867)$ & Percent $(\%)$ \\
\hline \multirow[t]{2}{*}{ Gender } & Male & 1,002 & 53.7 \\
\hline & Female & 865 & 46.3 \\
\hline \multirow[t]{5}{*}{ Age } & Below 25 & 132 & 7.1 \\
\hline & $25-34$ & 706 & 37.8 \\
\hline & $35-44$ & 631 & 33.8 \\
\hline & $45-54$ & 318 & 17.0 \\
\hline & 55 and above & 80 & 4.3 \\
\hline \multirow{6}{*}{ Religion } & Islam & 1,368 & 73.3 \\
\hline & Buddha & 191 & 10.2 \\
\hline & Sikh & 19 & 1.0 \\
\hline & Hindu & 123 & 6.6 \\
\hline & Christian & 161 & 8.6 \\
\hline & Others & 5 & 0.3 \\
\hline \multirow[t]{5}{*}{ Ethnic } & Malay & 1,243 & 66.6 \\
\hline & Chinese & 235 & 12.6 \\
\hline & Indian & 173 & 9.3 \\
\hline & Bumiputera Sabah and Sarawak & 203 & 10.9 \\
\hline & Others & 13 & 0.7 \\
\hline \multirow[t]{6}{*}{ Highest education level } & Secondary level & 264 & 14.1 \\
\hline & Certificate level & 206 & 11.0 \\
\hline & Diploma level & 414 & 22.2 \\
\hline & Bachelor's degree & 770 & 41.2 \\
\hline & Masters & 179 & 9.6 \\
\hline & $\mathrm{PhD}$ & 34 & 1.8 \\
\hline \multirow{4}{*}{ Employment status } & Government sector & 892 & 47.8 \\
\hline & Private sector & 683 & 36.6 \\
\hline & Self employed & 209 & 11.2 \\
\hline & Non-employed & 83 & 4.4 \\
\hline \multirow[t]{3}{*}{ Marital status } & Single & 489 & 26.2 \\
\hline & Married & 1,304 & 69.8 \\
\hline & Divorced/Widowed & 74 & 4.0 \\
\hline \multirow{2}{*}{ Residential area } & Urban & 1,295 & 69.4 \\
\hline & Rural & 572 & 30.6 \\
\hline \multirow[t]{3}{*}{ Household income (group) } & B40 (less than RM3,900) & 360 & 19.3 \\
\hline & M40 (RM3,900-8,300) & 1,149 & 61.5 \\
\hline & T20 (RM8,301 and above) & 358 & 19.2 \\
\hline
\end{tabular}

Table 3.

Descriptive analysis

\section{2}

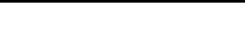


Item

1. What do you feel is the level of your financial stress today?

2. Are you satisfied with your personal finances?

3. How do you feel about your current financial situation?

4. How often do you worry about being able to meet your monthly living expenses?

5 . How confident are you of finding the money to pay for a financial emergency costing RM 1,000?

6 . How frequently do you find yourself eagerly awaiting for the next pay day?

7. How often does this happen to you - you want to go out to eat, go to movie or do something else and don't go because you can't afford to?

8 . How secure do you feel about your retirement plan?

9 . How confident are you that you will have a financially comfortable retirement?

Cronbach's alpha
Factor

loading

Anchoring scale

0.822

stress at all

Completely dissatisfied -

Completely satisfied

Feel completely overwhelmed - Not overwhelmed at all

Worry all the time - Never worry

No confidence - High confidence

All the time - Never

All the time - Never

Not secure - Very secure

No confidence - High confidence

0.790

0.838

0.797

0.852

0.775

0.77

0.751

0.792

0.927

0.927
Financial wellbeing among Malaysian households

293

Table 4.

Confirmatory factor analysis for FWB

\begin{tabular}{|c|c|c|c|c|c|c|c|c|c|c|}
\hline & \multirow[b]{2}{*}{$N$} & \multirow[b]{2}{*}{ Min } & \multirow[b]{2}{*}{ Max } & \multirow[b]{2}{*}{ Mean } & \multirow[b]{2}{*}{ Std. Dev } & \multicolumn{2}{|c|}{ Skewness } & \multicolumn{2}{|c|}{ Kurtosis } & \multirow{3}{*}{$\begin{array}{r}\text { Table } 5 . \\
\text { Descriptive statistics }\end{array}$} \\
\hline & & & & & & Statistic & $\mathrm{SE}$ & Statistic & $\mathrm{SE}$ & \\
\hline FWB & 1867 & 1.00 & 10.00 & 5.2148 & 1.86804 & 0.100 & 0.057 & -0.156 & 0.113 & \\
\hline
\end{tabular}

fairness of financial services in United Kingdom. Devlin (2009) developed an index that measures customers' perceived fairness of financial services using two fairness dimensions, namely, procedural justice and distributive justice. In contrast, this study constructs an index to measure subjective FWB modified from Prawitz et al. (2006) to reflect both present and future financial satisfaction. We only follow Devlin's (2009) technique to generate our FWB construct into an index score using Eqn (1) and Eqn (2). In Devlin's (2009) study, the index was developed from items that employed a 5-point Likert scale measurement, while the present study makes a minor modification to suit a 10-point Likert scale instead. We used the basic formula specified by Devlin (2009) to compute the index. Based on Devlin (2009), $m$ represents the number of maximum score per item (i.e. the maximum number on the Likert scale). Hence, we adjusted the $m$ in the following formula from 5 to 10 , since our measurement uses a 10-point scale.

$$
\text { Index Score }=[s-1] \times \frac{100}{[m-1]}
$$

where $m$ denotes the maximum score (10) per item and $s$ represents the respondent's selfreported score for each item, ranging from 1 to 10 . Hence, if the respondent answers 10 on the scale, his index score for the item is $=(10-1) \times 100 / 9=100$; if he answers 6 on the scale, his index score for the item is $=(6-1) \times 100 / 9=55.5$; and if the respondent answers 1 on the scale, his index score for the item is $=(1-1) \times 100 / 9=0$.

The FWBI scores for all the items generated in Eqn 1 are used to compute the overall index score for each respondent. To achieve this, we use the following formula: 
JABES 27,3

294

$$
\mathrm{FWBI}=\frac{\sum_{i-1} \text { Index Score }}{n}
$$

where the index scores are generated from Eqn 1 , while $n$ is the number of items (9) to produce the overall FWBI score for each respondent. By converting the score into an index, the highest attainable index is 100, reflecting a perfect score of FWB and no financial distress, and the lowest attainable index is 0 , reflecting the lowest level of FWB and a maximum level of financial distress. We adapt Prawitz et al.'s (2006) descriptive terminology to interpret the FWBI scores (Table 6).

\subsection{Objective 1: FWB of Malaysian households}

The first objective of this study is to assess the FWB of Malaysian households using the derived FWBI, and compare their FWB of B40, M40 and T20 households. From the FWBI construction from Section 4.3.2, results reveal that households, on average, have FWBI score of 46.83 (Table 6). As per the descriptive terminology for interpreting this index (Table 5), the results suggest that Malaysian households generally have an average FWB, reciprocally having an average level of financial distress. As expected, the subjective measure of FWB significantly differs among the three household categories. The B40 households have the lowest FWBI of 37.37, followed by the M40 where their FWBI is 46.11 and T20 households have the highest reported FWBI of 58.67. When we map the three income groups' FWBI score, the score clearly shows that the B40 group has poor FWB levels, and is therefore financially distressed. Meanwhile, M40 households have an average FWBI. Surprisingly, T20 households are in an only slightly better position than the M40 groups where the highincome earners also have a moderate level of FWB and moderate financial distress. One-way ANOVA tests indicate that the differences in the FWBI of each household income category are statistically significant at the $1 \%$ level $(F=111.291, p=0.000)$ (Table 7 and Table 8 ).

\begin{tabular}{lll}
\hline FWBI & & Descriptive terminology \\
\hline High & 100 & No financial distress/highest financial well-being \\
& $89-99$ & Extremely low financial distress/extremely high financial well-being \\
& $78-88$ & Very low financial distress/very good financial well-being \\
Moderate & $67-77$ & Low financial distress/good financial well-being \\
& $56-66$ & Moderate financial distress/moderate financial well-being \\
Low & $44-55$ & Average financial distress/average financial well-being \\
& $33-43$ & High financial distress/poor financial well-being \\
& $22-32$ & Very high financial distress/very poor financial well-being \\
& $11-21$ & Extremely high financial distress/extremely low financial well-being \\
& $0-10$ & Overwhelming financial distress/lowest financial well-being
\end{tabular}

Note(s): Adapted from: Prawitz et al. (2006)
Table 6.

Descriptive terminology for interpreting the FWB
Table 7.

FWBI of the low-, middle- and high income households

\begin{tabular}{lrrrrr}
\hline Household income category & $n$ & FWBI & SD & Min & Max \\
\hline B40 & 360 & 37.37 & 19.24 & 0.00 & 90.12 \\
M40 & 1,149 & 46.11 & 19.37 & 0.00 & 100.00 \\
T20 & 358 & 58.67 & 20.96 & 0.00 & 100.00 \\
Total & 1867 & 46.83 & 20.75 & 0.00 & 100.00
\end{tabular}


We further scrutinise the FWB by examining the scores for each item that was used to measure the index. The idea is to examine which items are better or more critical than others. Figure 1 depicts the mean score (over a maximum of 10) for each item of the FWB measurement, segregated according to household income groups. Clearly, the figure shows that B40 households score the lowest in all items (indicated by the blue bar), while highincome households (T20) have the highest FWB across all items. Among the nine (9) items, it appears that Malaysian households score the highest for their confidence in finding RM1,000 for financial emergencies - the T20 group scored highest for this item at 7.64, followed by the middle-income households (M40) that scored 5.66. The second highest score across all household income groups was reported as being able to eat out and go to watch movies. Even the B40 respondents scored highest for this item (4.82), compared to other items. Among the T20 households, the lowest scoring items were their feelings of financial stress (5.84) and satisfaction with personal finances (5.88). It can be observed that the mean score for all items was below 4.50 for the B40 households, and the lowest scoring item was for worrying about meeting monthly living expenses. Generally, the results indicate that Malaysian households across all household income group are not satisfied and feel distressed about their finances.
Financial wellbeing among Malaysian households

295

\begin{tabular}{lrrrrrr}
\hline & Sum of squares & \multicolumn{1}{c}{ df } & Mean square & $F$ & Sig & \\
\hline Between groups & $86,437.506$ & 2 & $43,218.753$ & 111.291 & 0.000 & Table 8. \\
Within groups & $723,862.754$ & 1864 & 388.338 & & & One-way ANOVA tests \\
Total & $810,300.260$ & 1866 & & & & \\
\hline
\end{tabular}

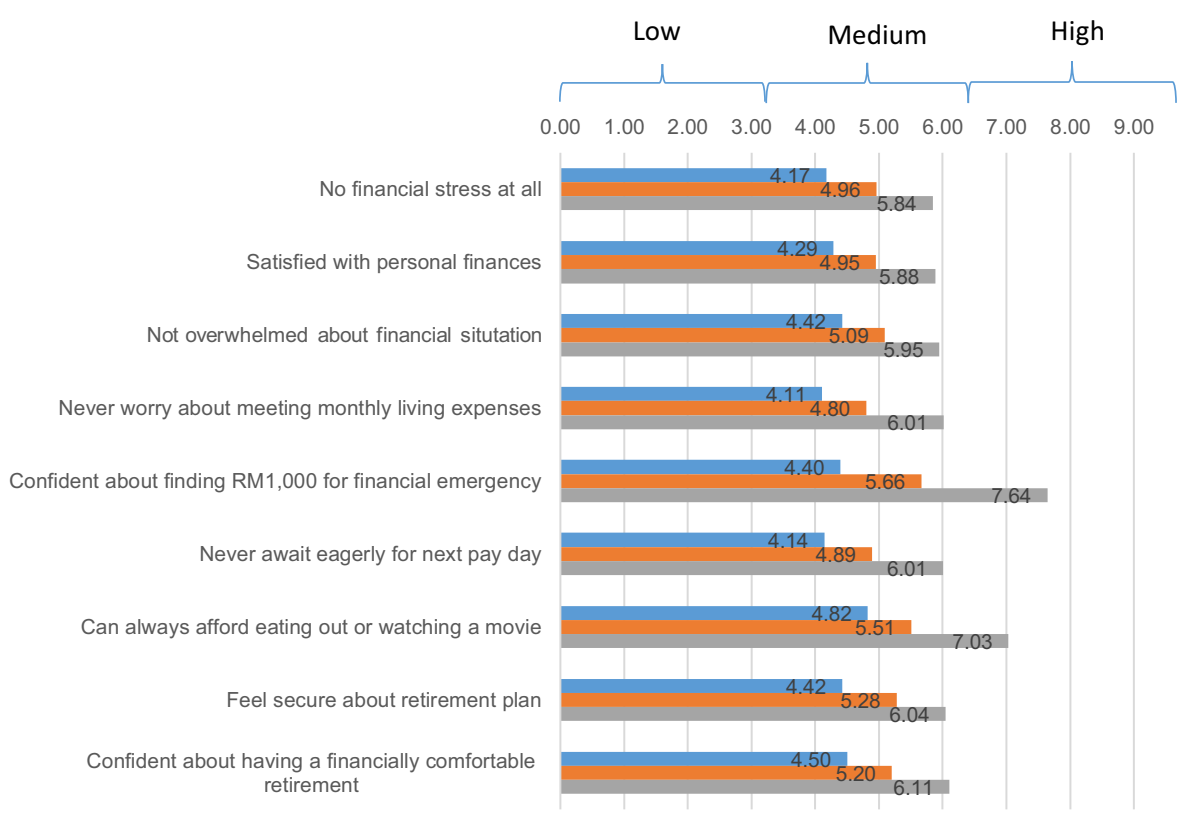

Figure 1. Scores of FWB by item 
JABES 27,3

\subsection{Objective 2: differences in FWB across socio-demographic factors}

The second objective of this paper is to examine the differences in FWBI across sociodemographic characteristics. The purpose is to be able to identify the groups that have low FWB based on socio-demographic characteristics. One-way ANOVA tests are conducted on FWB across socio-demographic factors such as age, marital status, education level, employment sector and others. As per Table 9, results show that the FWBI significantly differ across the categories of age $(F=13.352, p<0.000)$, education $(F=11.877, p<0.000)$, individual income level $(F=49.808, p<0.000)$, household income level $(F=79.446, p<0.000)$, employment $(F=7.994, p<0.000)$ and marital status $(F=8.370, p<0.000)$. Their FWB level draws parallel to their age, employment type, income and education levels, supporting the results of past literature (e.g. Ross and Huber, 1985).

Table 9 shows significant differences of FWBI across age groups, whereby higher age groups reported higher FWBI than their younger counterparts. These results support prior evidence that as people get older, they are more likely to have accumulated more financial assets and have a lower tendency to spend (Hansen et al., 2008). Similar results are also observed with regard to FWB and household income. The results infer a positive correlation between income earned by the household and their satisfaction level towards their finances. Thus, among Malaysians, the poorest households are the most affected group due to adverse changes to the financial circumstances, supporting the results of prior studies (e.g. Brown and Gray, 2016a; Mirowsky and Ross, 1999).

The results of the ANOVA tests also highlight significant differences in the FWBI across education levels. Those who attained the highest formal education (postgraduate level) reported having the highest FWBI (52.09), followed by those who completed their undergraduate studies (47.02). These results support prior studies that have suggested that education is associated with FWB, by way of increasing their human capital level and disposable income (Ross and Huber, 1985; Vosloo et al., 2014).

Apart from the above, the results also reflect that married and self-employed respondents are financially happier than their counterparts. Respondents who reported being married had an average FWB score of 48.04 versus those who reported are being single, divorced or widowed, with an average score of 44.36 and 40.88, respectively. Meanwhile, the association between type of employment and FWB indicated that those who were self-employed scored the highest at 48.29. These results are consistent with previous studies like Ross and Huber (1985), Joo and Grable (2004) and Falahati and Paim (2011).

Nevertheless, the findings of our study were contrary to previous studies that indicate significant differences in FWB across religious groups (Helliwell, 2006), ethnic groups (Thoits and Hewitt, 2001) and residential areas (Gerdtham and Johannesson, 2001). An interesting conclusion that can be made from these results is that no matter what race, religion or place of residence, Malaysians in general are feeling distressed with their financial situation.

\section{Conclusion and implications}

The current economic challenges faced by Malaysian households have attracted special attention from policymakers, researchers and academics. The main thrust of this study is to explore the FWB levels of Malaysian households. Adapting the IFDFW scale by Prawitz et al. (2006) and the method of computing an index by Devlin (2009), this study develops an FWBI using subjective measures, and across two time dimensions (present and future retirement), based on the perceptions and emotions of individuals regarding their current and future financial satisfaction. The index was employed to measure the FWBI simultaneously across three Malaysian household income categories and socio-demographic characteristics. As the index is able to capture the perceptions and emotions of Malaysians regarding their FWB, it will act as a complement to the existing indexes such as the MWI and MFWBI and will 


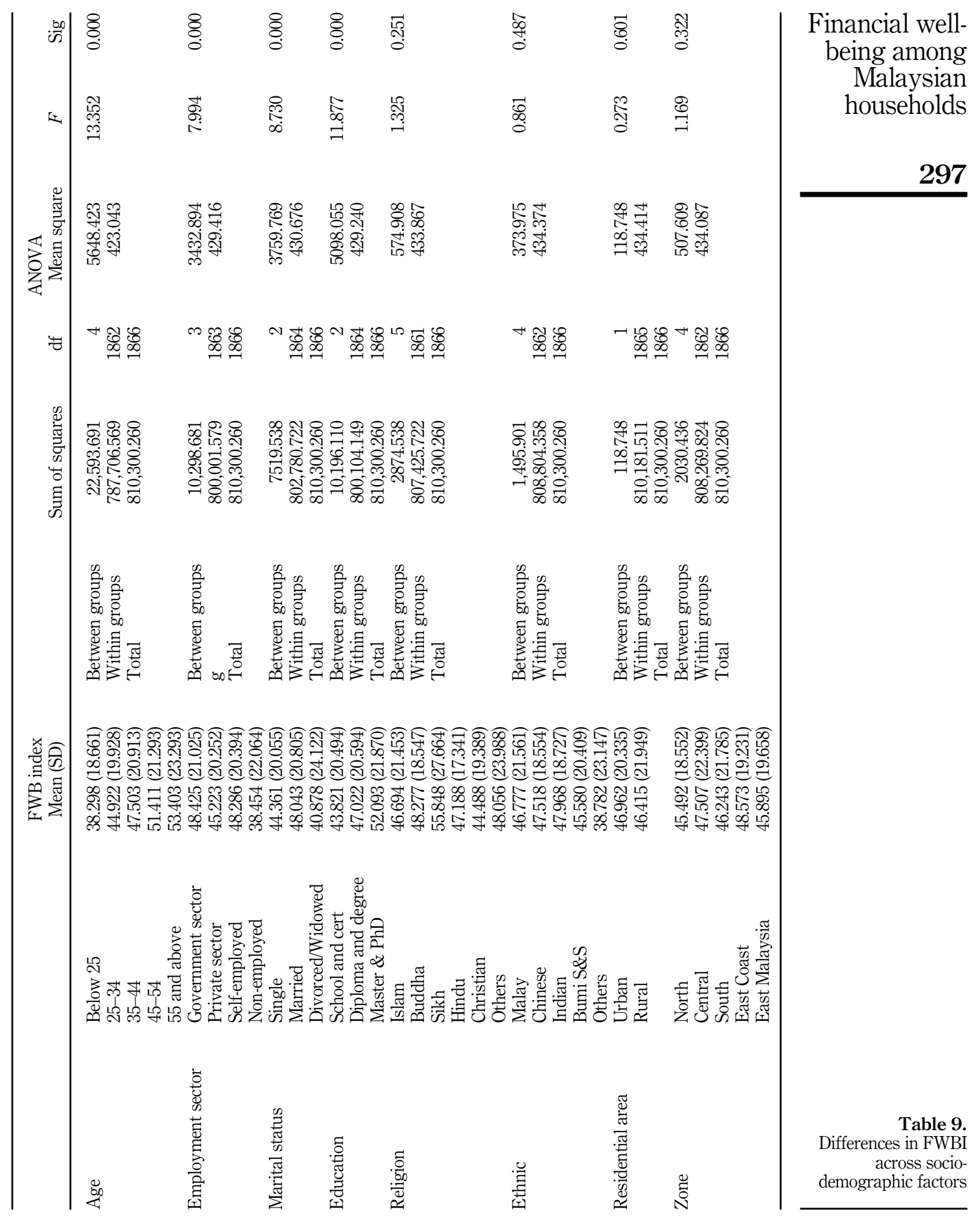


JABES 27,3

298 enlighten the government and policymakers on the general state of Malaysian households' FWB/distress.

This study finds evidence that the overall Malaysian households' FWB level is between average and poor, while the FWBI across the income groups differed significantly. The B40's FWBI is lowest, reflecting the financial hardships faced by the group, and reciprocally suggests a high level of financial distress. In line with the existing literature, this study finds that the FWB of Malaysian households differs according to socioeconomic background including age, education, employment and marital status (Ross and Huber, 1985; Joo and Grable, 2004; Falahati and Paim, 2011). Nevertheless, the FWBI for religion, ethnic and residential area was found to have no significant difference among the respondents. This suggests that the detrimental effects of the FWB are perceived by all Malaysian households nationwide regardless of their religion, ethnicity as well as their residential areas. It stands to reason then that any targeted interventions to increase the level of FWB in the general population must consider the influential socioeconomic backgrounds and foremost their current financial positions. The findings confirm that individuals who are more matured and educated are more likely to have higher FWB. This is line with previous studies that shown that higher financial literacy (an indicator of education and maturity) resulted in higher level of FWB (Falahati and Paim, 2011). Thus, an understanding about matters related to finance should be given at an early age. Further, the findings of the study suggest that the government's focus should not be restricted to any specific religion, ethnic group or residential area, but rather to the household income. The income position of the comparison groups provides more valuable information regarding a household's potential future financial position. Therefore, in tackling the FWB of the population, the advocates should consider the factors of determination and their magnitude based on each income group.

Upon scrutiny of each FWB item that is used to form the FWBI (Figure 1), the study finds that Malaysian households are quite stressed about their personal finances and often worry about meeting their monthly expenses. The low-income households, especially, tend to eagerly wait for their upcoming pay, suggesting that they live on rather tight monthly budgets. However, most Malaysian households are confident about being able to come up with a financial emergency expense and appear to be able to afford dining out and going for movies. Hence, it can be inferred that spending for leisure and lifestyle purposes is regarded as quite important for Malaysian households, despite having difficulty living on tight monthly budgets. This is a signal to service providers such as restaurant and entertainment operators to strategically price their products and services to cater for customers according to their willingness to pay, or, in other words, their price elasticity of demand. Segmenting the market according to price elasticities of demand would be mutually beneficial for both the service provider and customers of different income categories because Malaysian households seem to value the experience of dining out and watching movies, and this clearly contributes to their perceived financial satisfaction. Segmenting the market and pricing products and services according to elasticities of demand would also benefit service providers as they are able to widen their market share and increase profits.

This study is, of course, not without limitations. First, one may argue that there may be drawbacks of using subjective measures rather than objective measures such as monetised income measures in the development of the FWBI. However, we strongly believe that the use of subjective measures provides a more superior and genuine reflection of one's financial satisfaction, happiness and well-being. FWB may be difficult to gauge using objective income measures since each individual's life situation, including their expenditures, lifestyle, family size and life conditions, will differ. Another possible limitation of the study would be that this study is cross-sectional in nature; hence, it captures the perceptions of Malaysians at one point in time. A true examination of causality will be greatly enhanced through a longitudinal study that could effectively capture the changes and effects of the determinants of FWB over 
time. This will help the government track the effectiveness of their policies, which is in line with the national Shared Prosperity Vision of becoming a high-income nation by year 2030. The third limitation is in term of our sampling, where we focused on households located in five major regions (Central, Southern, Northern, East Coast and East Malaysia) in Malaysia. While our findings focus on Malaysian households, future researchers may consider adapting the FWBI in other contexts across the world.

\section{Note}

1. MYR100 $=$ USD24 (exchange rate as in November 2018)

\section{References}

Azman, N.S., Hamdan, R., Suki, N.M. and Shari, A. (2017), "Determinants of household indebtedness in East Malaysia: an evaluation”, Advanced Science Letters, Vol. 23 No. 9, pp. 8154-8159.

Balakrishnan, N. (2016), "36\% of Malaysian employers will Be downsizing this year", available at: http://says.com/my/news/36-employers-may-be-cutting-down-on-employees-this-year.

Brown, S. and Gray, D. (2016a), "Household debt and financial assets: evidence from Germany", Journal of the Royal Statistical Society: Series A, Vol. 171 No. 3, pp. 615-643.

Brüggen, E.C., Hogreve, J., Holmlund, M., Kabadayi, S. and Löfgren, M. (2017), "Financial well-being: a conceptualization and research agenda”, Journal of Business Research, Vol. 79, pp. 228-237.

Consumer Financial Protection Bureau (2015), Financial Well-Being: The Goal of Financial EducationReport, Consumer Financial Protection Bureau, Iowa City, IA.

Delafrooz, N. and Paim, L.H. (2011), "Determinants of financial wellness among Malaysia workers", African Journal of Business Management, Vol. 5 No. 24, p. 10092.

Delafrooz, N., Paim, L., Sabri, M.F. and Masud, J. (2010), "Effect of financial wellness on the relationship between financial problem and workplace productivity", World Applied Sciences Journal, Vol. 10 No. 8, pp. 871-878.

Department of Statistics Malaysia (2019), Population and Demographic, available at: https://www.dosm. gov.my/v1/index.php?r=column/cthemeByCat\&cat $=155 \&$ bul_id $=$ aWJZRkJ4UEdKcUZpT2tVT 090Snpydz09\&menu_id=L0pheU43NWJwRWVSZklWdzQ4TlhUUT09.

Devlin, J. (2009), "Measuring consumer perceptions of fairness in financial services", American Marketing Association Marketing and Public Policy Conference 2009, Washington, p. 94.

Dickason-Koekemoer, Z. and Ferreira, S. (2019), "A conceptual model of financial well-being for South African investors", Cogent Business and Management, Vol. 6 No. 1, p. 1676612.

Diener, E., Lucas, R.E. and Oishi, S. (2002), "Subjective well-being", Handbook of Positive Psychology, Vol. 16 No. 2, pp. 63-73.

Drever, A.I., Odders-White, E., Kalish, C.W., Else-Quest, N.M., Hoagland, E.M. and Nelms, E.N. (2015), "Foundations of financial well-being: insights into the role of executive function, financial socialization, and experience-based learning in childhood and youth", Journal of Consumer Affairs, Vol. 49 No. 1, pp. 13-38.

Economic Planning Unit (2015), Rancangan Malaysia Kesebelas 2016-2020. Pertumbuhan Berpaksikan Rakyat, Percetakan Nasional Malaysia Berhad, Putrajaya.

Falahati, L. and Paim, L. (2011), "Toward A framework of determinants of financial management and financial problems among university students", African Journal of Business Management, Vol. 5 No. 22, pp. 9600-9606.

Garman, E.T., MacDicken, B., Hunt, H., Shatwell, P., Haynes, G., Hanson, K.C. and Woehler, M.B. (2007), "Progress in measuring changes in financial distress and financial well-being as A result of financial literacy programs", Consumer Interests Annual, Vol. 53, pp. 199-211. 
JABES 27,3

300

Gerdtham, U.G. and Johannesson, M. (2001), "The relationship between happiness, health, and socioeconomic factors: results based on Swedish microdata", The Journal of Socio-Economics, Vol. 30, pp. 553-557.

Gerrans, P., Speelman, C. and Campitelli, G. (2014), "The relationship between personal financial wellness and financial well-being: a structural equation modelling approach", Journal of Family and Economic Issues, Vol. 35 No. 2, pp. 145-160.

Greninger, S.A., Hampton, V.L., Kitt, K.A. and Achacoso, J.A. (1996), "Ratios and benchmarks for measuring the financial well-being of families and individuals", Financial Services Review, Vol. 5 No. 1, pp. 57-70.

Hansen, T., Salgsvold, B. and Moum, T. (2008), "Financial satisfaction in old age: a satisfaction paradox or a result of accumulated wealth?”, Social Indicators Research, Vol. 89 No. 2, pp. 323-347.

Helliwell, J.F. (2006), "Well-being, social capital and public policy: what's new?”, The Economic Journal, Vol. 116 No. 510, pp. 1-16.

Helliwell, J.F., Huang, H., Grover, S. and Wang, S. (2014), "Good governance and national well-being: what are the linkages?", OECD Working Papers on Public Governance. No. 25, OECD Publishing, Paris, doi: 10.1787/5jxv9f651hvj-en (accessed 14 November 2018).

Hurd, M., Juster, F.T. and Smith, J.P. (2003), "Enhancing the quality of data on income recent innovations from the HRS", Journal of Human Resources, Vol. 38 No. 3, pp. 758-772.

Jariah, M. (2007), Testing of Malaysia's Financial Well-Being Scale, Paper presented in the Seventh Biennial Conference 2007 ACFEA, 4 - 7 July 2007, Putrajaya.

Joo, S. (1998), Personal Financial Wellness and Worker Productivity, Virginia Polytechnic Institute and State University, Blacksburg, Unpublished Doctoral Dissertation.

Joo, S.H. and Grable, J.E. (2004), "An exploratory framework of the determinants of financial satisfaction”, Journal of Family and Economic Issues, Vol. 25 No. 1, pp. 25-50.

Joo, S.H., Durband, D.B. and Grable,J. (2008), "The academic impact of financial stress on college students", Journal of College Student Retention: Research, Theory and Practice, Vol. 10 No. 3, pp. 287-305.

Kemisola-Christianah, O., Sabri, M.F. and Badari, S.A.Z. (2019), "Financial well-being of Nigerian family in ikeja lagos state Nigeria", Management, Vol. 7 No. 1, pp. 1-8.

Kim, J., Garman, E.T. and Sorhaindo, B. (2003), "Relationships among credit counseling clients' financial well-being, financial behaviors, financial stressor events, and health", Journal of Financial Counseling and Planning, Vol. 14 No. 2, pp. 75-87.

Krejcie, R.V. and Morgan, D.W. (1970), "Determining sample size for research activities”, Educational and Psychological Measurement, Vol. 30 No. 3, pp. 607-610.

Lanz, M., Sorgente, A. and Danes, S.M. (2019), "Implicit family financial socialization and emerging adults' financial well-being: a multi-informant approach", Emerging Adulthood. doi: 10.1177/ 2167696819876752.

Maleske, R.T. (1995), Foundations for Gathering and Interpreting Behavioral Data, Brooks/Cole Publishing Company, Pacific Grove. CA.

Mirowsky, J. and Ross, C. (1999), "Economic hardship across the life course", American Sociological Review, Vol. 64, pp. 548-569.

Mokhtar, N. and Husniyah, A.R. (2017), "Determinants of financial well-being among public employees in putrajaya, Malaysia”, Pertanika Journal of Social Science and Humanities, Vol. 25 No. 3, pp. 1241-1260.

Mokhtar, N., Husniyah, A.R., Sabri, M.F. and Talib, M.A. (2015), "Financial well-being among public employees in Malaysia: a preliminary study", Asian Social Science, Vol. 11 No. 18, p. 49.

Porter, N.M. (1990), Testing A Model of Financial Well-Being, Virginia Tech, Doctoral Dissertation.

Porter, N.M. and Garman, E.T. (1992), "Money as part of a measure of financial well-being”, American Behavioral Scientist, Vol. 35 No. 6, pp. 820-826. 
Prawitz, A.D., Garman, E.T., Sorhaindo, B., O’Neill, B., Kim, J. and Drentea, P. (2006), "Incharge financial distress/financial well-being scale: development, administration, and score interpretation”, Journal of Financial Counseling and Planning, Vol. 17 No. 1, pp. 34-50.

Pudney, S. (2011), "Perception and retrospection: the dynamic consistency of responses to survey questions on well-being", Journal of Public Economics, Vol. 95 No. 3, pp. 300-310.

Ross, C.E. and Huber, J. (1985), "Hardship and depression", Journal of Health and Social Behavior, Vol. 26 No. 4, pp. 312-327.

Sabri, M.F. and Falahati, L. (2012), "Estimating a model of subjective financial well-being among college students", International Journal of Humanities and Social Science, Vol. 2 No. 18, pp. 191-199.

Sabri, M.F. and Zakaria, N.F. (2015), "The influence of financial literacy, money attitude, financial strain and financial capability on young employees' financial well-being”, Pertanika Journal of Social Sciences and Humanities, Vol. 23 No. 4, pp. 827-848.

Shim, S., Xiao, J.J., Barber, B.L. and Lyons, A.C. (2009), "Pathways to life success: a conceptual model of financial well-being for young adults", Journal of Applied Developmental Psychology, Vol. 30 No. 6, pp. 708-723.

Sivaramakrishnan, S. and Srivastava, M. (2019), "Financial well-being, risk avoidance and stock market participation", International Journal of Financial Services Management, Vol. 9 No. 4, pp. 326-344.

Strumpel, B. (1977), "Economic means for human needs: social indicators of well-being and discontent", Social Indicators Research, Vol. 4 No. 2, pp. 241-245.

Subramaniam, G., Ali, E. and Maniam, B. (2014), "Subjective financial well-being and incidence of indebtedness among young workers in Malaysia”, Business Studies Journal, Vol. 6, pp. $57-122$.

The Star Online (2015), "Hong leong group downsizing workforce", available at: https://www.thestar. com.my/business/business-news/2015/10/21/hong-leong-group-downsizing-workforce/ (accessed 14 November 2018).

Thoits, P.A. and Hewitt, L.N. (2001), "Volunteering work and well-being", Journal of Health and Social Behaviour, Vol. 42, pp. 115-131.

Vosloo, W., Fouché, J. and Barnard, J. (2014), "The relationship between financial efficacy, satisfaction with remuneration and personal financial well-being", The International Business and Economics Research Journal, Vol. 13 No. 6, pp. 1456-70.

Yin-Fah, B.C., Masud, J., Hamid, T.A. and Paim, L. (2010), "Financial well-being of older peninsular Malaysians: a gender comparison”, Asian Social Science, Vol. 6 No. 3, p. 58.

Zaimah, R., Masud, J., Haron, S.A., Othman, M., Awang, A.H. and Sarmila, M.D. (2013), "Financial wellbeing: financial ratio Analysis of married public sector workers in Malaysia”, Asian Social Science, Vol. 9 No. 14, p. 1.

Zainol, Z., Daud, Z., Khairol, A.N.H., Rashid, R.A. and Alias, N. (2016), "Exploring factors that contribute to individual indebtedness among young muslims", International Journal of Economics and Financial Issues, Vol. 6 No. 7S, pp. 320-328.

\section{Further reading}

Beaumont, J. (2011), "Measuring national well-being - discussion paper on domains and measures", Monthly Digest of Statistics, Vol. 790, pp. 1-34, doi: 10.1057/mds.2011.80.

Brown, S. and Gray, D. (2016b), "Household finances and well-being in Australia: an empirical Analysis of comparison effects", Journal of Economic Psychology, Vol. 53, pp. 17-36, doi: 10.1016/ j.joep.2015.12.006.

Choi, S.L., Heo, W., Cho, S.H. and Lee, P. (2020), “The links between job insecurity, financial well-being, and financial stress: a moderated mediation model", International Journal of Consumer Studies, Vol. 44 No. 4, pp. 353-360, doi: 10.1111/ijcs.12571.
Financial wellbeing among Malaysian households 
JABES 27,3

302

Diener, E. and Biswas-Diener, R. (2002), “Will money increase subjective well-being?”, Social Indicators Research, Vol. 57 No. 2, pp. 119-169.

Diener, E., Sandvik, E., Seidlitz, L. and Diener, M. (1993), "The relationship between income and subjective well-being: relative or absolute?", Social Indicators Research, Vol. 28 No. 3, pp. 195-223.

Gasper, D. (2005), "Subjective and objective well-being in relation to economic inputs: puzzles and responses", Review of Social Economy, Vol. 63 No. 2, pp. 177-206.

Kingdon, G.G. and Knight, J. (2006), "Subjective well-being poverty vs. income poverty and capabilities poverty?", The Journal of Development Studies, Vol. 42 No. 7, pp. 1199-1224.

Leonard, S., Zhang, J.W. and Howell, R. (2019), "Spending well: how time perspectives impact consumer values and financial decisions among middle-aged adults", Research in Human Development, Vol. 16 No. 2, pp. 135-155.

Malaysia Well-being Report (2013), The Malaysian Well-Being Index 2013, Economic Planning Unit. Prime Minister's Department, Putrajaya.

Momtaz, Y.A., Ibrahim, R., Hamid, T.A. and Yahaya, N. (2011), "Socio-demographic predictors of elderly's psychological well-being in Malaysia", Aging and Mental Health, Vol. 15 No. 4, pp. 437-445.

Musek, J. and Polic, M. (2014), "Personal well-being”, in Michalos, A.C. (Ed.), Encyclopedia of Quality of Life and Well-Being Research, Springer Netherlands, Prince George, BC, pp. 4752-4755.

National Population and Family Development Board Malaysia (2015), Family Well-Being Index Report Malaysia 2011, National Population and Family Development Board (NPFDB), Kuala Lumpur.

National Population and Family Development Board Malaysia (2017), Report on Malaysian Family Well-Being Index 2016, National Population and Family Development Board (NPFDB), Kuala Lumpur.

Randall, C., Corp, A. and Self, A. (2014), "Measuring national well-being: life in the UK", Office for National Statistics, pp. 1-52, available at: http://www.ons.gov.uk/ons/dcp171766_352740.pdf (accessed 14 November 2018).

Sabri, M.F., MacDonald, M., Hira, T.K. and Masud, J. (2010), "Childhood consumer experience and the financial literacy of college students in Malaysia", Family and Consumer Sciences Research Journal, Vol. 38 No. 4, pp. 455-467.

The Malaysian Well-Being Report (2013), Economic Planning Unit (EPU), available at: http://www. epu.gov.my/sites/default/files/Pembentangan \%20MWI\%202013_2Disember\%202013.pdf (accessed 14 November 2018).

\section{Corresponding author}

Rozaimah Zainudin can be contacted at: rozaimah@um.edu.my

For instructions on how to order reprints of this article, please visit our website:

www.emeraldgrouppublishing.com/licensing/reprints.htm

Or contact us for further details: permissions@emeraldinsight.com 